Click www.researchjournal.co.in/online/subdetail.html to purchase.

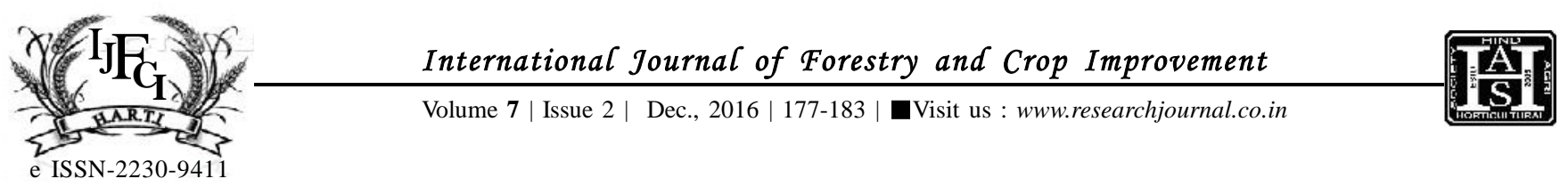

RESEARCH ARTICLE

DOI: $10.15740 / \mathrm{HAS} / \mathrm{IJFCI} / 7.2 / 177-183$

\title{
Trailing of agroforestry in Haridwar
}

\author{
HIMSHIKHA AND CHARAN SINGH
}

\begin{abstract}
It is interesting to know about trailing of agroforestry by the farmers in any region particularly when it contains rural agrarian areas. This study is an attempt to understand fertilizer application, fuelwood collection, incentives and income supports. This work has focused on fertilizer sources, fuel sources, fuel wood-fodder collection, various incentives and income support provided by agroforestry to its adopters living in the study area. For this purpose field data was collected from 365 respondents reported who focused exclusively on agroforestry. Findings revealed that in agroforestry, chemical fertilizers were used by 98.36 per cent, FYM/organic manure by 95.89 per cent and green manures by 58.63 per cent farmers to increase the agroforestry production. Farmers use domestic manure and commercially available chemical fertilizers. Approximately 98 per cent farmers responded positively on income support that was considered very important (48.77\%). It was concluded that fuelwood collection, incentives, income supports are some reasons behind agroforestry in the region and farmers are actively involving themselves to adopt methods like soil fertility enhancements to raise production and widespread promotion of agroforestry.
\end{abstract}

KEY WORDS : Agroforestry, Farmers, Income, Practice

HOW TO CITE THIS ARTICLE : Himshikha and Singh, Charan (2016). Trailing of agroforestry in Haridwar. Internat. J. Forestry \& Crop Improv., 7 (2) : 177-183, DOI: 10.15740/HAS/IJFCI/7.2/177-183.

ARTICle ChronicAL : Received : 18.10.2016; Revised : 16.11.2016; Accepted : 29.11.2016 